\title{
The Legal Consequences of Informed Consent for Doctors and Patients in Theurapeutic Agreements
}

\begin{tabular}{c} 
Iip Verra Selvia ${ }^{1 \text { (corresponding author) }}$, Arief Suryono ${ }^{\mathbf{2}}$ Sapto Hermawan $^{\mathbf{3}}$ \\
${ }^{1}$ Faculty of Law, Universitas Sebelas Maret Surakarta, Indonesia; iversze_1496@student.uns.ac.id \\
${ }^{2}$ Faculty of Law, Universitas Sebelas Maret Surakarta, Indonesia; ariefsuryono@staff.uns.ac.id \\
${ }^{3}$ Faculty of Law, Universitas Sebelas Maret Surakarta, Indonesia; saptohermawan@ @ staff.uns.ac.id \\
\hline Submitted: May 20, 2020 -Revised: June 22, 2020 -Accepted: June 24, 2020 -Published: June 24, 2020 \\
\hline
\end{tabular}

\begin{abstract}
Informed consent is a requirement for the occurrence of therapeutic agreements between doctors and patients. Therapeutic agreements are agreements where healing effort (inspanningverbittenes) is constituted as legal object. A patient who has given a consent is considered to understand the benefits and risks of medical treatment he would receive. However, the existence of informed consent does not make any doctor immune to the law. If a doctor works outside the professional standards and operational standards that apply and is proven by the professional association, then a doctor could be sanctioned according to applicable regulations. On the other hand, the patient is required to be cooperative in providing information and complying with the medical procedures. The existence of a therapeutic agreement results in both doctor and patient being bound to each other's rights and obligations.
\end{abstract}

Keywords: informed consent; therapeutic agreement; doctor; patient

\section{INTRODUCTION}

Health is an important aspect in human life that affects one's productivity. Logical consequence by accepting health paradigm is that any activities must be oriented to health insight. ${ }^{(1)}$ However, there are times when one's health is disturbed due to many factors and unable to do his activity. Therefore, one would seek for health treatment in health facilities, be it private clinic or even hospital.

Before one undergoes any health measures, usually the doctor gives information regarding patient's illness and possible medical measures that would cure the patient. This is called informed consent. Informed consent is an agreement by patients for doctors to do medical intervention to cure patients' illness. ${ }^{(2)}$

When a medical treatment is high risk, a written informed consent by the patient is required. ${ }^{(3)}$ The purpose is not to free the doctor from the responsibility of risk or from the demands of compensation from his patient, but to motivate the patient to cooperate properly regarding the risk of treatment that may harm patient's being. Therefore, informed consent must be understood from both the patients' interests and doctors' obligation point of views.

In fact, informed consent process does not happen properly between doctors and patients thus leads to misunderstanding in therapeutic agreement. Consequence (Indonesia Dictionary) is a result of a doing. Legal consequence means a result of a legal relation. Therefore, this study intends to reanalyze the legal consequence of informed consent in therapeutic agreement between doctors and patients

\section{METHODS}

\section{Type of Research}

This type of this legal research was normative or doctrinal legal research which was also referred to as library research or document study because this research was carried out toward written regulations or other legal materials. ${ }^{(4)}$

\section{Source of Legal Material}

\section{Primary Legal Material}

The primary legal material used consists of statutory regulations, official records, minutes in the making of regulations and judges' decisions. ${ }^{(4)}$ Primary legal material in this research includes: 
1) Constitution 1945

2) Civil Code

3) Criminal Code

4) Law No. 29 of 2004 concerning Medical practice

5) Law No. 36 of 2009 concerning Health

6) Indonesia Health Ministry Regulation concerning Approval on Medical Action

7) Ministerial Decree of Indonesia Health Ministry No.434/MENKES/SK/X/1983 concerning Medical Code of Ethics (Kode Etik Kedokteran Indonesia/KODEKI)

8) Circular Letter of the Supreme Court No. 3 of 1963

9) Circular Letter of Director General of Health Services, 1997

\section{$\underline{\text { Secondary Legal Material }}$}

The main secondary legal materials are textbooks containing principles of law and classic perspectives of high qualification alumnus. ${ }^{(4)}$ Secondary legal materials used in this research includes:

1) Scientific books of law

2) International journals of law

3) National journals of law

\section{Tertiary Legal Material}

Tertiary legal materials are materials which hints or explains primary and secondary legal materials. Tertiary legal materials used in this research includes:

1) Indonesia Dictionary

2) Internet sites related to informed consent and/or therapeutic agreement

\section{Data Collection and Analysis Technique}

Legal materials collection technique includes how to obtain legal materials in the research which supporting and suitable legal materials collection technique for this research is document study (library research). ${ }^{(4)}$ Document study is legal materials collection technique conducted through written legal materials using content analysis. This technique is used to explore the theoretical basis by studying the primary, secondary, and tertiary legal materials using both printed and electronic media.

In this research, author used qualitative analysis technique namely by collecting data, qualifying data, then connecting it with theories related to the problem and finally drawing conclusions to determine the results, which produce descriptive data. This descriptive data is what is stated by the informants verbally or in writing and observed behavior which then are analyzed as a whole

\section{RESULTS}

\section{What is the Position of Informed Consent in Therapeutic Agreement?}

Article 1 section 1 Health Ministry Regulation No. 290/MENKES/PER/III/2008 concerning Approval of Medical Actions defines informed consent or approval of medical actions as approval that is given by the patient or patient's closest family after receiving a complete explanation regarding the medical or dental action that will be performed on the patient. It has to be emphasized that the definition of informed consent is an approval given by patient only when patient has received explanation from the doctor which could be an explicit, such as a written approval, or implied consent. ${ }^{(5)}$

Although therapeutic agreement has specificity compared to other agreement in general, therapeutic agreement is considered as legal in the eye of law as long as it fulfills the requirement of legal agreement that is regulated in Article 1320 of Civil Code, which are:

1) There is agreement from those who bind themselves

2) There is capability to make an agreement

3) It is about certain matter(s)

4) For some legal reason/permitted

As regulated in Law No. 29 of 2004 concerning Medical Practice Article 51 letter (a) stated that doctors or dentists in conducting medical practice have an obligation to deliver medical services according to professional 
standards and procedure standards as well as patients's needs. Civil relations between doctors and patients generate rights and obligations between each party. Informed consent is a patient's right which is also an obligation that must be carried out by the doctor.

Although informed consent is an absolute right for patients, patients are obliged to be cooperative and to give truthful information about their health conditions without anything concealed as it is reiterated in Article 53 letter (a) Law No. 29 of 2004 concerning Medical Practice. ${ }^{(6)}$ The principle aspect of informed consent is the understandable information for patients, therefore it is important for doctors who will conduct a medical action to deliver the explanation completely with common terms that is easy to comprehend by patients. ${ }^{(7)}$ Do not let the information from the doctor occur incorrectly because the patient or the patient's family cover the actual state of the patient's health. Informed consent can be divided into two forms which are: ${ }^{(8)}$

1) Expressed

a) Orally

b) Written

2) Implied or tacit consent

a) Normal or constructive consent

b) Emergency

Should informed consent is given in written form for both high risk interventions or common interventions because it may be an evidence if there is any dispute between patients and doctors or dentists. ${ }^{(9)}$ In Circulatory Letter of Director General of Medical Services YM.00.03.2.2.1296, written medical action agreement must consists of:

1) Known and signed by two witnesses

2) Does not require any stamps

3) Original form must be put in patient's medical record

4) The form must be filled and signed within 24 hours prior the medical action conduct

5) The doctor must also sign the form as a prove that the information has been delivered and explained adequately

6) As substitute for signature, illiterate patient or patient's family must affix the right thumb fingerprint.

Other than asking for patient's approval, doctors are obliged to note anything related to patients in medical record. Medical record is a document of notes and patient's identity, examination, treatment, other medical actions, and services done to patients in a health facility.

Doctors must keep patient's secrecy. Patient's secrecy includes the identity, and anything related to patient's illness. In some conditions, patient's secrecy can be revealed if: ${ }^{(10)}$

1) patient agrees mendapat persetujuan pasien

2) in accordance to applied law

3) it is court's order

4) it is for public interest

Therapeutic transaction between patients and doctors does not begin when the patient get into the examination room as it is fathomed by many people, but it begins since the doctor expressed the willingness by oral statement or implied statement by showing actions that gives impression of willingness such as accepting registration, giving out waiting number, providing and filling medical records, and others. ${ }^{(11)}$

\section{What is the Position of Therapeutic Agreement for the Doctor and the Patient?}

According to Ministerial Decree of Indonesia Health Ministry No. 434/MEN.KES/X/1983 concerning Medical Code of Ethics, therapeutic transaction or therapeutic agreement is a relationship between a doctor and a patient that is carried out in an atmosphere of mutual trust (confidential) which could be overwhelmed by any emotions, hopes, and worries of human being. The relationship between a doctor and a patient is a civil law relationship, where the patient comes to the doctor to be cured and the doctor promises to try to cure patient's illness. ${ }^{(9)}$ There are at least three purposes in therapeutic agreement (Anggraeni Endah Kusumaningrum, 2016) which are to cure and prevent the disease, to alleviate sufferings, and to guide the patient. ${ }^{(12)}$

Civil law relationship are legal relations conducted by parties who are in an equal position, at least when the parties come in a certain legal relation. In therapeutic agreement, there are legal subject and legal object. Legal subject includes the patient, the health workforce or doctor or dentist. Meanwhile, the legal object is any maximum effort to cure the patient. However, it is not only about doctors' responsibility since therapeutic agreement is a bilateral contract type that gives rights and obligations to not only doctors but also patients as related party. ${ }^{(6)}$

The consequence of therapeutic agreement between a doctor and a patient create an equal position between the doctor and the patient. Therefore, whatever the doctor carries out for the patient, it must involve the patient. 
The equal form between the doctor and the patient is proven by the informed consent or medical action agreement. The state guarantees the equality between a doctor and a patient by regulating informed consent in Indonesia Health Ministry Regulation No. 290/ MENKES/PER/III/2008 concerning Approval on Medical Action Article 1 Section 1.

Article 1313 of Civil Code defines agreement as an act by which one or more people commit themselves to one or more people. As any agreements in general, therapeutic agreement is considered as long as it subjects to the legal condition of agreement as regulated in Article 1320 of Civil Code, which are: ${ }^{(13)}$

1) Agreement between they who bind themselves; Agreement should not happen if there is any coercion and fraud as regulated in Article 1323 to 1328 of Civil Code. That there must be an agreement between a doctor and a patient in health efforts is also affirmed in Article 39 of Law No. 29 of 2004 concerning Medical Practice which stated medical practice should be conducted base on the agreement between doctors or dentists and patients in an effort to maintain health, prevent disease, improve health, treat disease and restore health.

2) The capability in making agreement; Capability is an absolute requirement in agreement. Article 1330 of Civil Code classifies incapable parties, which includes:

a) Immature people.

b) People who are under supervision because of the mental retardation or intellectual disability that unable them in making decisions and acting before the law

c) Women, or under legally regulated circumstances, and in general anybody to whom the law forbids to make any certain agreements. However, this clause has been eliminated by the Circulatory Letter of Supereme Court No. 3 of 1963 dated August $4^{\text {th }} 1963$ which concerns Article 108 and 110 of Civil Code, which is about the prohibition of a wife to to carry out legal actions and to appear before the court without permission from the husband's assistance, is no longer valid.

3) Certain matter(s): The matter in therapeutic agreement is the effort to cure.

4) Legal reasons: It means that the agreement does not violate the law, decency, and public order. This is regulated in Article 1337 of Civil Code that a cause if prohibited if it is prohibited by the law, or if it is against the good decency or public order.

The requirements of agreement in Article 1320 section (1) and (2) of Civil Code are subjective requirements because it relates with the subjects or the agreeing people, meanwhile Article 1320 section (3) and (4) of Civil Code are objective requirements of agreement. If subjective requirements are violated, then the agreement will be abolished. If it is the objective requirements that are violated, then the agreement will be abolished in the name of law.

Civil relationship between a doctor and a patient begin from the agreement where in Civil Code, there are two kinds of agreements: ${ }^{(9)}$

1) Inspanningverbintenis, or namely effort agreement, meaning both agreed parties must put maximum effort to realize what was agreed.

2) Resultaatverbintenis, is an agreement that the promised party will give a real result according to what was promised

Civil law relationship between a doctor and a patient is categorized as Inspanningverbintenis because any effort by the doctor in the therapeutic agreement is a form of health effort in order to achieve patient recovery based on patient's complaints and medical knowledge the doctor has. A doctor does not guarantee to cure the disease but with endeavour and medical skill, a doctor is expected to help in the recovery effort. ${ }^{(14)}$ Legally, the relationship between a doctor and a patient is an endeavour relationship or maximum effort, therefore a doctor does not promise to cure, but to maximally help the patient to recover. ${ }^{(15)}$ It is common that there is misunderstanding in the society where patients assume doctors must heal the patients. As has been discussed in previous section, it is not the healing that is promised by the doctors but the maximum effort by the doctors to heal the patients according to defined Medical Professional Standard. It is because medical knowledge is uncertain, people would say: Medicine is a science of the uncertainty, an art of the probability. This uncertainty is very affected by many factors, such as immunity, type and stage of the disease, drug quality, patient's compliance towards doctor's and nurse's advice.

Although therapeutic agreement is, in general, an effort agreement or inspanningverbintenis, there are times when therapeutic agreements shift to resultaatverbintenis which promised object is a tangible result. Under some circumstances a doctor may promises the work result to the patient, for example, a denstist who makes dentures, an orthophaedic who make prosthetic limbs, a plastic surgeon who fix one's nose shape or other body part. Moreover, in Europe, surgeries that are considered easy and the result can be promised, it is included in resultaatsverbintenis, while surgeries that are considered as complicated and difficult are included as inspanningsverbintenis. ${ }^{(16)}$ 
Rights and obligations of both the doctor and the patient in therapeutic agreement is regulated in Law No. 29 of 2004 concerning Medical Practice where Article 50 and Article 51 regulate the rights and obligations of doctors and dentists, and Article 53 regulates rights and obligations of patients. Other regulation regarding similar matter also can be found in Circulatory Letter of Director General of Health Services No. YM 02.04.3.5.2504 concerning Guidelines for The Rights and Obligations of Doctors and Patients. Now, the author would like to present it in table 1 and 2.

Table 1. Rights and obligations of doctors and patients according to Indonesia Law No. 29 of 2004 Concerning Medical Practice Article 50, 51, and 53 Regarding Rights and Obligations of Doctors and Patients

\begin{tabular}{|c|c|c|}
\hline Party & Rights & Obligations \\
\hline Patiens & 5 & 4 \\
\hline Doctors & 4 & 5 \\
\hline
\end{tabular}

Table 2. Rights and obligations of doctors and patients according to Circulatory Letter of Director General of Health Services No. YM 02.04.3.5.2504 concerning Guidelines for The Rights and Obligations of Doctors and Patients

\begin{tabular}{|c|c|c|}
\hline Party & Rights & Obligations \\
\hline Patiens & 16 & 5 \\
\hline Doctors & 9 & 12 \\
\hline
\end{tabular}

According to the presented tables, we could see that most rights are owned by patients while the least obligations also owned by patients. It is understandable because although in informed consent a doctor and a patient are in the equal position, each party comes from a different background. Moreover, patients are in sick condition and might be unable to think clearly thus may present in worried emotional state, wondering if they can fully recover or become defected or even dead. The position of doctors and hospitals is strong, becausedoctors possess the medical knowledge and hospitals have large capital. Therefore, to balance the condition patients are given many rights, while doctors and hospitals are given many obligations. ${ }^{(10)}$

\section{DISCUSSION}

Medical science is an art and science that is perfected by experience meaning the approach to a disease could be different from one doctor to another while it is still based on the accounted science. ${ }^{(17)}$ In every action done by a doctor, whether a diagnostic or therapeutic action, the risk always presents including accidents and complications. If the doctor has performed in a lege artis manner; careful, thorough, and in accordance with medical professional standards, then the doctor cannot be blamed if there is any adverse event or even death. The honor of the medical profession lies in the patient's trust in the profession, therefore doctors must not abuse patients' weaknesses and must adhere to the ethical standards of KODEKI, with the following principles:

1) Primum non nocere: no intention to hurt, injure, or harm the patient

2) Beneficence: the carried out medical action is only for patient's benefit

3) Justice: a doctor should not be discriminative, for instance differentiating patients according to their wealth

4) Honest, appreciating patient's rights, acknowledging the limitation of competence, giving a truthful information to patients

The proposition about the medical profession according to Hippocrates is that:

Every doctor must try to master his knowledge as well as possible; must maintain the dignity of his profession; must become a saint and devote himself full time to his profession, as well as scientific and social integration.

Doctors can be prosecuted criminal and civil litigation if malpractice occurs in medical treatment. There is an important difference between ordinary crime and medical crime. In ordinary crimes, the main concern is the consequences, while in medical crime is the cause. Although fatal, if there is no element of neglect or error that cause the fatality, the doctor cannot be blamed. Basically, medical malpractice is a violation of professional obligations. For medical profession, the resolution of medical services dispute is considered better if it is resolved through a professional court rather than in a general court. ${ }^{(18)}$ 


\section{Violations by Doctors Related to Civil Law}

1) Breach of contract or contract injury (Article 1239 of the Civil Code);

2) Committing acts against the law or onrechtmatigedaad (Article 1365 of Civil Code);

3) Committing negligence resulting in losses/harms (Article 1366 of Civil Code):

4) Committing negliglence in work as the person in charge of a particular job (Article 1367 Section 3 of Civil Code).

$$
\text { Violations by Doctors Related to Crime Law }
$$

1) Deceiving sufferers or patients (Article 378 of Crime Code);

2) Making false letter of statement (Article 263, 267 of Crime Code);

3) Committing negligence causing death or injuries (Article 359,360,361 of Crime Code);

4) Violating decency (Article 290 Section (1), 294 Section (2), 285, 286 of Crime Code);

5) Carrying out abortion without medical indications (Article 299, 346, 347, 348, 349, 350 of Crime Code);

6) Leaking medical secret that is reported by the patienrs (Article 322 of Crime Code);

7) Intentionally leaving the patient with no help (Article 304 of Crime Code);

8) Not giving help to a person who is in danger of death (Article 351 of Crime Code);

9) Giving or selling fake drugs (Article 386 of Crime Code);

10) Conducting euthanasia (Article 344 of Crime Code).

To standardize the quality of doctors, Indonesian Doctor's Association (Ikatan Dokter Indonesia/IDI) has issued general professional standards, whereas standardization of specialized medical procedures is issued by the related colleague. Doctor, as a profession, possess inherent competencies (abilities), authority and responsibilities. The competence here is related to whether the doctor has attended medical education and graduated with a doctor's degree. The authority relates to whether the doctor has a practice permit that is legalized by IDI/PDGI (Persatuan Dokter Gigi Indonesia/Indonesian Dentist's Association) recommendation letter. Meanwhile, the responsibilities include ethical responsibilities (as regulated in KODEKI) and legal responsibilities.

From this discussion, we can understand that most therapeutic agreements are inspanningsverbintenis where doctors are obliged to carry out the maximum effort for patient recovery. Along with it, doctors must manage ethical and moral values, the oath, as well as responsible towards the general law (crime, civil, and administrative law) and health law. It must be underlined that the existence of informed consent does not make doctors immune in the eye of law, although it may protect doctors from malpractice allegation. In other words, a patient can sue the doctor who make negligence and mistakes, but if the doctor can prove that he has made every effort to heal patients according to Professional Standards and Operational Procedure Standards, then the doctor cannot be blamed.

\section{CONCLUSION}

Informed consent is proof of equal legal standing between the doctor and the patient where the patient is involved in every decision of medical action. The existence of informed consent does not make the doctor invulnerable in the eyes of the law and free from all claims, but this is evidence that the doctor has involved the patient in making medical action decisions and that every medical action received by the patient has been based on his agreement.

Informed consent must be interpreted and understood critically from the point of view of the patient's interests or doctor's obligations prior to the therapeutic agreement. Doctors and patients must try to work well, given the high risks that must be faced can harm or endanger the patient. The doctor must make the maximum effort armed with reasons, abilities, and skills in order to provide the best medical treatment, while the patient must be active and cooperative while receiving medical treatment.

As an agreement in general, therapeutic agreements must comply with the legal conditions of the agreement in the Civil Code even though the object of law is in the form of healing efforts (inspaningverbitenes). Therapeutic agreements also create legal relations between doctors and patients in the form of obligations and rights that bind to one another. The therapeutic agreement is ended if the patient is recovered or there is agreement between both parties. 


\section{REFERENCES}

1. Mustajab. Juridical Analysis of the Legal Relationship Between Doctors and Patients in Health Services (Analisis Yuridis Hubungan Hukum Antara Dokter dan Pasien Dalam Pelayanan Kesehatan). Jurnal Ilmu Hukum Legal Opinion. 2013;1(4):1-11.

2. Wardhani IASK. Implementation of the Approval of Medical Action (Informed Consent) in the Therapeutic Agreement by Health Personnel to Hospital Patients in Bali Province (Implementasi Persetujuan Tindakan Kedokteran (Informed Consent) dalam Perjanjian Terapeutik oleh Tenaga Kesehatan Terhadap Pasien Rumah Sakit di Provinsi Bali). Jurnal Magister Hukum Udayana. 2014;3(1):1-17.

3. Komalawati V. The Role of Informed Consent in Therapeutic Transactions (Peranan Informed Consent dalam Transaksi Terapeutik). Bandung: PT Citra Aditya Bakti; 2002.

4. Soekanto S, Mamudji S. Normative Legal Research (Penelitian Hukum Normatif). Jakarta: PT. Raja Grafindo Persada; 2004.

5. Hendrojono. Limits of Doctors' Malpractice Legal Liability in Therapeutic Transactions (Batas Pertanggungjawaban Hukum Malpraktik Dokter Dalam Transaksi Terapeutik). Surabaya: Srikandi; 2007.

6. Salim HS, Nurbani ES. Development of Innominaate Contract Law in Indonesia (Perkembangan Hukum Kontrak Innominaat di Indonesia). Jakarta: Sinar Grafika; 2014.

7. Darmini N, Septiana R. Informed Consent for Medical Practices at Grhasia Pakem Hospital Yogyakarta (Informed Consent Atas Tindakan Kedokteran di Rumah Sakit Grhasia Pakem Yogyakarta). Jurnal Mimbar Hukum. 2014;26(2):234-6.

8. Guwandi J. Informed Consent \& Informed Refusal. Jakarta: Balai Penerbit FKUI; 2006.

9. Machmud S. Law Enforcement and Legal Protection for Doctors Allegedly Conducting Medical Malpractice (Penegakan Hukum dan Perlindungan Hukum Bagi Dokter yang Diduga Melakukan Medikal Malpraktek). Bandung: Karya Putra Darwati; 2012.

10. Putra S. Inspanningsverbintenis dan Resultaatsverbintenis in Therapeutic Transactions in Relation to Law No. 8 of 1999 concerning Consumer Protection (Inspanningsverbintenis dan Resultaatsverbintenis dalam Transaksi Terapeutik Kaitannya dengan UU No. 8 Tahun 1999 tentang Perlindungan Konsumen). Jurnal Hukum. 2001;8(18):199-211.

11. Kinanti AD, et al. The Urgency of Application of Informed Consent Mechanisms to Prevent Malpractice Claims in Therapeutic Agreements (Urgensi Penerapan Mekanisme Informed Consent Untuk Mencegah Tuntutan Malpraktik Dalam Perjanjian Terapeutik). Privat Law Journal. 2016;3(2):108-13.

12. Kusumaningrum AE. Therapeutic Transaction Analysis, a Means of Legal Protection for Patients: The Role of MKDKI in Carrying Out Health Law Enforcement (Analisis Transaksi Terapeutik Sarana Perlindungan Hukum Bagi Pasien: Peran MKDKI Dalam Melakukan Penegakan Hukum Kesehatan). Jurnal Ilmiah “Dunia Hukum”. 2016;1(1):1-17.

13. Mayasari DE. Juridical Review of Informed Consent as a Patient's Rights and Doctor's Obligations (Tinjauan Yuridis Tentang Informed Consent Sebagai Hak Pasien dan Kewajiban Dokter). Varia Justicia. 2017;13(2):93-102.

14. Hariyani S. Medical Disputes [Alternative Settlement Between Doctors and Patients] (Sengketa Medik [Alternatif Penyelesaian Antara Dokter dengan Pasien]). Jakarta: Diadit Media; 2005.

15. Novika RO. The Legal Position of the Therapeutic Agreement (Between the Hospital and the Patient) in the Approval of Medical Measures According to the Civil Code (Kedudukan Hukum Perjanjian Terapeutik (Antara Rumah Sakit dan Pasien) Dalam Persetujuan Tindakan Medik Menurut Kitab Undang-Undang Hukum Perdata). JOM Fakultas Hukum. 2015;2(1):1-15.

16. Amelyn F. Capita Selekta Medical Law (Kapita Selekta Hukum Kedokteran). Jakarta: PT. Grafikatama Jaya; 1991.

17. Richards, Edward P, Katharine C. et al. Law and Physician: A Practical Guide. Boston, TX: Little Brown and Co; 1993.

18. Azwar A. Some Notes about the Consumer Protection Act and its Impact on Health Services (Beberapa Catatan tentang UU Perlindungan Konsumen dan Dampaknya terhadap Pelayanan Kesehatan). Paper on Day Seminar on Consumer Protection for Health Services. 1999. 